\title{
LIBERDADE DE EXPRESSÃO NÂO É DISCURSO DE ÓDIO
}

Taciana Nogueira de Carvalho Pieroni ${ }^{1}$

Escola Superior Dom Helder Câmara (ESDHC)

Artigo recebido em: 18/08/2019.

Artigo aceito em: 21/10/2019.

\section{Resumo}

Este artigo aborda o direito de liberpelo contrário, são práticas atentatórias dade de expressão como direito fundamental exercido sob a égide do princípio constitucional da dignidade da pessoa humana. O tema principal é a distinção entre liberdade de expressão e discurso de ódio. Condutas preconceituosas e discriminatórias não são direito de liberdade de expressão, muito aos direitos fundamentais. O pluralismo não ampara tais condutas, uma vez que o Estado Democrático de Direito é pautado pela tolerância.

Palavras-chave: dignidade humana; discurso de ódio; liberdade de expressão.

\section{FREEDOM OF SPEECH IS NOT HATE SPEECH}

\section{Abstract}

This article outlines the right to freedom of expression as the fundamental right exercised under the aegis of the constitutional principle of Human Dignity. The main issue is the distinction between freedom of speech and hate speech. Prejudiced and discriminatory behavior cannot be considered as freedom of speech, on the contrary, they are prejudicial practices to fundamental rights. The Pluralism cannot sustain such conducts, since the "State of Rights" is marked by tolerance.

Keywords: freedom of expression; hate speech; tolerance.

1 Mestre em Ciências Jurídicas pela Pontifícia Universidade Católica do Rio de Janeiro (PUC-RJ). Professora universitária de cursos de graduação e pós-graduaçấo nas áreas de Direito Constitucional e Direito Administrativo. E-mail: taciana.pieroni@gmail.com 


\section{Introdução}

O presente artigo tem por escopo a distinção entre o direito de liberdade de expressão e os discursos de ódio, tendo por premissa uma abordagem do referido direito fundamental à luz de consideraçóes sobre a consagração do princípio da dignidade da pessoa humana - princípio fundamental e fundante da ordem constitucional pátria. A análise do tema passa por uma verificação da liberdade de expressão e sua alocação na primeira dimensão de direitos fundamentais, ao lado de outras liberdades, não menos importantes, para a consagração dos direitos fundamentais nos principais textos constitucionais do mundo ocidental contemporâneo.

A dignidade da pessoa humana é o princípio nuclear do ordenamento jurídico, o que o torna indissociável dos direitos fundamentais. A relação Dignidade, Direitos Fundamentais e Constituiçáo é diretriz da conduta estatal e particular por ser a referência da instituição da ordem jurídica.

Não há unanimidade doutrinária acerca do número de geraçôes ou dimensôes de direitos fundamentais. Para Bonavides (2010), seriam cinco as dimensóes, uma vez que o autor em comento defende o direito à paz como uma dimensão autônoma dos direitos fundamentais - a quinta dimensão. ${ }^{2}$

Sendo assim, a primeira dimensão de direitos fundamentais corresponde aos direitos de liberdade e aos direitos políticos e tem como referências as duas revoluçôes liberais burguesas. $\mathrm{O}$ direito de liberdade de expressão enquadra-se na primeira dimensão, ao lado de outras liberdades como a de locomoção, a de consciência e crença e a de reunião.

As características dos direitos fundamentais como a universalidade, historicidade, inalienabilidade, indivisibilidade e limitabilidade foram apresentadas neste trabalho, com o escopo de destacar a inconstitucionalidade da relação entre liberdade de expressão e discurso de ódio. Ora, se os direitos fundamentais são limitados, não há como confundir o exercício do direito de liberdade de expressão com a possibilidade do cometimento de ofensas e discriminaçôes preconceituosas,

2 A primeira geração de direitos humanos, como explicitado acima, surgiu ao lado do Estado Liberal pós-revoluçóes burguesas e teve como marcos a Declaração Francesa dos Direitos do Homem e do Cidadão, de 1789, além da Constituiçẫo Estadunidense de 1787 (diplomas legais, como a Magna Carta Inglesa de 1215 e o Bill of Rights, de 1688, também são matrizes da primeira geração, tendo destaque as revoluçóes burguesas nesse reconhecimento por conta da recogniçắo das referidas geraçóes por Vasak, em consonância com a marca predominante). Os direitos sociais, econômicos e culturais correspondem à segunda geração e foram explicitados pela primeira vez nas Constituiçốes do México de 1917 e Weimar, de 1919, tendo como objetivo a persecução da igualdade. A terceira geraçăo é expressa pelos direitos coletivos, como o direito ao meio ambiente, direito ao desenvolvimento e direito de comunicaçáo, que tenderam a se cristalizar em fins do século XX. Para os seguidores da corrente defendida por Bonavides (2010), uma quarta geração de direitos fundamentais refere-se aos direitos à democracia, direito à informação e direito ao pluralismo, sendo a globalização política na esfera da normatividade jurídica o marco introdutório desses direitos. Como já mencionado, Bonavides (2010) concebe a ideia de que o direito à paz se trasladou da terceira geraçăo, esculpida por Vasak, para uma quinta dimensão autônoma de direitos fundamentais. 
o que se evidenciou com a apresentação do princípio da unidade da Constituiçáo.

Por fim, apresentou-se a repressão constitucional a qualquer forma de discriminação, com a demonstração de que não há nenhum embasamento em nome da liberdade de expressão que possibilite a ideia de práticas atentatórias à dignidade humana.

\section{$1 \mathrm{O}$ direito de liberdade de expressáo e a dignidade da pessoa humana}

O direito de liberdade de expressão consagrado no texto da Constituição Pátria de 1988 está intrinsecamente associado ao princípio da dignidade da pessoa humana, assim como todos os demais direitos fundamentais prescritos no referido diploma legal.

$\mathrm{Na}$ esfera jurídica, a primazia da pessoa com fundamento na dignidade configura-se como resposta à crise do Positivismo Jurídico, desencadeada pela derrota dos nazifascistas, uma vez que tais movimentos políticos e militares se ampararam na legalidade para promover os horrores do holocausto e difundir práticas de barbárie em nome da lei (PIOVESAN, 2003).

Odesfecho daSegunda Guerra Mundial, que teve como uma das consequências o julgamento de Eichman, em Jerusalém, inspirou Hannah Arendt a cunhar a expressão "banalidade do mal", com a finalidade de explicar o comportamento dos algozes do período bélico. Eles agiam indiferentemente a qualquer juízo ético, o que chama atenção para a necessidade irrefutável, sobretudo em razão de sua decretação pelas Naçóes Unidas, de impingir valores éticos aos ordenamentos jurídicos (PIOVESAN, 2003). A dignidade passa, entấo, a ser reivindicada como princípio e como cerne dos sistemas jurídicos.

Destaque-se o dispositivo da Carta Constitucional da República Alemã de 1949, que se tornou fonte inspiradora para outras constituiçóes: "Art. $1^{\circ}$ (proteção da dignidade da pessoa humana) A dignidade da pessoa humana é inviolável. Todas as autoridades públicas têm o dever de a respeitar e proteger" (SARLET, 2002, p. 26).

A dignidade da pessoa humana é o princípio-núcleo do ordenamento jurídico, sendo assim visceral e indissociável dos direitos fundamentais. É o que se pode denominar aspecto pragmático-constitucional - relação entre os direitos fundamentais e a dignidade da pessoa humana na ordem constitucional. Destarte, a tríade - Dignidade, Direitos Fundamentais e Constituição - é a diretriz da conduta estatal e particular, porquanto se trata do conjunto fundante da ordem jurídica como um todo. 
Firma-se, então, a concepção de que os direitos fundamentais são a concretização da dignidade humana dentro da ordem constitucional; concretização evidenciada sob o aspecto de informadora de todo o ordenamento jurídico.

Essencial esclarecer que os direitos fundamentais alçados à condição de princípios constitucionais tornam-se essenciais na salvaguarda de um princípio maior ${ }^{3}$ : o princípio da dignidade da pessoa humana.

A análise, portanto, do direito de liberdade de expressão, não pode ser dissociada da dignidade da pessoa humana, tendo em vista o destaque desse princípio concebido como o centro normativo constitucional do texto de 1988 .

\section{A liberdade de expressáo como direito de primeira dimensão e as características dos direitos fundamentais}

Foi em 1979, durante conferência proferida pelo publicista francês Karel Vasak, em cursos do Instituto Internacional de Estrasburgo, que se estabeleceu o entendimento sobre o surgimento dos direitos fundamentais em geraçóes ou dimensóes (para se usar um termo mais aceito na atualidade) de acordo com determinado contexto histórico-político-social (BONAVIDES, 2010).

A primeira geração ou dimensão de direitos fundamentais corresponde aos direitos de liberdade: os direitos civis e políticos. São direitos oponíveis ou de resistência perante o Estado. Os marcos históricos são as Revoluçóes Francesa e Americana. A titularidade é atribuída sob a perspectiva individual, com destaque para liberdades de consciência e crença, de reunião e de liberdade de expressão, entre outras (BONAVIDES, 2010).

Além da importância da análise dos direitos fundamentais sob a visão da onda geracional ou dimensional, é de extrema relevância também a compreensão desses direitos sob a perspectiva das várias características que lhe são atribuídas. Podem ser destacadas as características da universalidade, da limitabilidade ou relatividade, da historicidade, da inalienabilidade e da constitucionalização.

A característica da universalidade relaciona-se à titularidade dos direitos fundamentais. Basta a qualidade de ser humano como condição suficiente para o exercício desses direitos, não de todos, pois certo é que existem determinadas peculiaridades que não permitem a generalização dessa característica para todos os direitos fundamentais indistintamente (MENDES; BRANCO, 2014).

3 A conclusão de que o princípio da dignidade da pessoa humana é um superprincípio não pode ser analisada sem consideraçóes críticas. Tome-se como exemplo a ediçâo do Ato Institucional n. 5 durante o período da Ditadura Militar e que se apresentava preliminarmente amparado na dignidade humana. Não é o caso de se "glamourizar" o princípio da dignidade, mas, tão somente, constatar que, de fato, a existência digna é o alicerce do ordenamento fundado sob a égide da Constituição de 1988. O AI 5 é um caso emblemático de justificaçâao de retrocessos acerca das conquistas de direitos fundamentais, tendo a dignidade como base para o cometimento das mais absurdas violaçōes a esses direitos, em uma clara deturpação do significado dessa condição intrínseca da natureza humana. 
Sobre a historicidade, pode-se evidenciar que os direitos fundamentais são impulsionados por lutas. Não surgem, obviamente, todos simultaneamente e estấo em processo evolutivo permanente a partir das demandas sociais contextualizadas em determinada época (MENDES; BRANCO, 2014). De acordo com Sarlet (2005, p. 27), o processo de reconhecimento dos direitos fundamentais "é de cunho essencialmente dinâmico e dialético, marcado por avanços, retrocessos e contradiçóes, ressaltando, dentre outros aspectos, a dimensão histórica e relativa dos direitos fundamentais [...]".

A inalienabilidade se coaduna com a perspectiva de que os direitos fundamentais são indisponíveis, estando calcada na dignidade da pessoa humana, já explanada em item anterior deste trabalho. Importante destacar que nem todos os direitos fundamentais apresentam essa característica. Destaque-se:

Uma vez que a indisponibilidade se funda na dignidade humana e esta se vincula à potencialidade do homem de se autodeterminar e de ser livre, nem todos os direitos fundamentais possuiriam tal característica. Apenas os que visam resguardar diretamente a potencialidade do homem de se autodeterminar deveriam ser considerados indisponíveis. Indisponíveis, portanto, seriam os direitos que visam resguardar a vida biológica - sem a qual não há substrato físico para o conceito de dignidade - ou que intentem preservar as condiçôes normais de saúde física e mental, bem como a liberdade de tomar decisōes sem coerção externa (SARLET, 2005, p. 145).

A constitucionalização dos direitos fundamentais relaciona-se a sua consagração em normas jurídicas. Essa característica explica a distinção entre as expressóes direitos humanos e direitos fundamentais, ${ }^{4}$ uma vez que a primeira tem uma acepção de postulaçóes proclamadas em diplomas internacionais e a segunda é reservada pela peculiaridade de positivação em diplomas normativos de cada Estado (SARLET, 2005).

A indivisibilidade dos direitos fundamentais estatui que os direitos fundamentais pertencem a um único sistema protetivo, no qual o exercício de um desses direitos pressupóe o exercício de outros, em uma verdadeira relação de interdependência.

Por último, a característica notadamente mais marcante é limitabilidade ou relatividade dos direitos fundamentais, não raras vezes objeto de incompreensão

4 Não será objeto de análise neste trabalho o aprofundamento na abordagem sobre a distinção dos conceitos de direitos humanos e direitos fundamentais. 
e controvérsias. Os direitos não são absolutos, ${ }^{5}$ são limitados. As limitações externas são necessárias para que se assegure o exercício de outros direitos, com vistas a conciliar as exigências da vida em sociedade, trasladadas na ordem pública, ética, autoridade do próprio Estado. De acordo com Carvalho (2009, p. 717), as restrições aos direitos fundamentais fixam-se em três funçôes:

A) função adequadora, em que a restrição de um deles serve para possibilitar que outros direitos se exerçam sem sobreposiçóes, tendo a maior eficácia possível;

B) funçâo dirimente, que tem lugar no contexto específico da colisão de direitos fundamentais, caracterizada pelo exercício conflitante por parte de dois ou mais titulares de direitos contrapostos, servindo a restriçẫo de alguns deles para evitar a repetição desses conflitos no futuro, sem a necessidade de recorrer a ulteriores intervençóes administrativas ou jurisdicionais;

C) função comunitária, que se liga à conjugação entre os direitos fundamentais e os bens ou interesses coletivos merecedores de tutela, sendo a restrição instrumento de garantia desses bens, interesses e valores comunitários que importa preservar.

A compreensão da relação intrínseca entre dignidade humana e direitos fundamentais, bem como das características presentes em tais direitos, é essencial neste trabalho para a abordagem mais específica do objeto principal de análise, que é a liberdade de expressão. Há uma deturpação no entendimento do significado e exercício do direito fundamental de liberdade de expressão, sob as vertentes constitucionais que o consagram, conforme previsão no art. $5^{\circ}$, IV, referente à liberdade de manifestação do pensamento, bem como do mesmo dispositivo, inc. IX, que assegura a liberdade de expressão da atividade artística, intelectual, científica e de comunicação.

Liberdade de expressão não se confunde com discurso de ódio, não é concessão de direito para achincalhar, humilhar ou discriminar. Situem-se os dispositivos constitucionais supramencionados:

Art. $5^{\circ}$ garantindo-se aos brasileiros e aos estrangeiros residentes todos são iguais perante a lei, sem distinção de qualquer natureza, no país a inviolabilidade do direito à vida, à liberdade, à igualdade, à segurança e à propriedade, nos termos seguintes:

[...]

5 Merece destaque a acepção doutrinária majoritária: a dignidade da pessoa humana é um princípio absoluto, o que justificaria a impossibilidade de limitaçóes aos direitos de incolumidade física, que proíbem a escravizaçâa, a tortura e os tratamentos cruéis e degradantes. 
IV- é livre a manifestação do pensamento, sendo vedado o anonimato

$[\ldots]$

IX- é livre a expressão da atividade intelectual, artística, científica e de comunicação, independentemente de censura ou licença (CARVALHO, 2009, p. 774).

A liberdade de expressão possibilita a exteriorização do que se pensa sobre os mais variados assuntos, garante a difusão de ideias, opinióes, visóes de mundo, ideologia, assim como assegura aos meios de comunicação a possibilidade de efetuarem suas escolhas no mister de informar. Como corolário do Estado Democrático de Direito, a salvaguarda dessa liberdade, ao lado das outras liberdades individuais, é o esteio das mais variadas atividades artísticas, das diversas ciências, tanto as exatas quanto as biológicas, e inibe cerceamentos às revelaçôes culturais folclóricas, indígenas e eruditas.

A democracia tem como pressuposto a liberdade de falar, escrever, cantar, dançar, demonstrar o experimento científico, pesquisar, expor pontos de vista e contrapor-se às convicçôes de outrem. A liberdade de expressão é como a patente registrada do regime democrático, posto que náo há democracia sem voz para explanar e ser ouvida.

Como primeiro marco histórico de reconhecimento ao direito à liberdade de expressão aponta-se ato do Parlamento Inglês, datado de 1695, o qual vedava a censura. A Declaraçáo Universal dos Direitos do Homem e do Cidadão pós-Revolução Francesa assegurava a livre manifestação do pensamento, especificamente em seu art. $11 .^{6} \mathrm{E}$ não se pode olvidar a menção ao maior berço histórico ao direito de expressar-se livremente - a Constituiçáo Estadunidense com a consagração da liberdade de palavra e de imprensa na primeira emenda, datada de 1791.7 A Declaração Universal de Direitos Humanos de 1948 (ONU, $1948)^{8}$ também explicitou tal direito ao conferir a toda pessoa o direito à liberdade de pensamento e expressão (SCHREIBER, 2006).

Em síntese preliminar, a liberdade de expressão, em conjunto com os demais direitos fundamentais, tem como matriz referencial o princípio da dignidade da pessoa humana, com o qual se interliga diretamente e se edifica como direito intrínseco ao próprio regime democrático.

6 "Art. $11^{\circ}$ - A livre comunicaçấo das ideias e das opiniôes é um dos mais preciosos direitos do homem. Todo cidadăo pode, portanto, falar, escrever, imprimir livremente, respondendo, todavia, pelos abusos desta liberdade nos termos previstos na lei" (DECLARAÇĀO..., 1789).

7 "Emenda I - O Congresso não legislará no sentido de estabelecer uma religiāo, ou proibindo o livre exercício dos cultos; ou cerceando a liberdade de palavra, ou de imprensa, ou o direito do povo de se reunir pacificamente, e de dirigir ao Governo petiçóes para a reparaçăo de seus agravos".

8 "Art. $18^{\circ}$ - Toda pessoa tem direito à liberdade de opiniấo e expressáo; este direito inclui a liberdade de, sem interferências, ter opinióes e de procurar, receber, transmitir informaçóes e ideias por quaisquer meios e independentemente de fronteiras" (ONU, 1948). 
Questấo intrigante, porém, é a vertente caracterizadora dos direitos fundamentais como direitos limitados ou limitáveis. Como já exposto, a limitabilidade é a característica dos direitos fundamentais, que merece atenção especial. O próprio texto constitucional estabelece limites a serem observados no exercício do direito de expressar livremente ao contrapô-lo com a proibição do anonimato, ao salvaguardar o direito de resposta quando outros bens jurídicos também tutelados pela Constituição forem atingidos.

Sobre a possibilidade de limitaçôes de ordem infraconstitucional, o destaque é para o art. 220 da Constituição, que promove a exclusão de toda e qualquer possibilidade de censura no exercício da liberdade de expressão e de outras liberdades - entendida como a impossibilidade de intervenção oficial prévia ou posterior. Outrossim, o mesmo dispositivo em apreço abre caminho para regulação de diversôes e espetáculos, com indicações de faixas etárias, para restriçóes a propagandas de tabaco, bebidas alcoólicas e medicamentos, além de garantir meios legais para a impugnação de programaçôes de rádios e televisôes que possam ser nocivas ao meio ambiente e que não priorizem finalidades educativas, culturais, artísticas, informativas e de respeito a valores éticos e sociais da pessoa e da família.

\section{Limites do direito de liberdade de expressáo em caso de colisão com outros direitos fundamentais}

O texto constitucional é uno e indivisível. Ao se partir para uma reflexão isolada de uma norma da Constituição sem uma reflexão sob o viés do princípio da unidade, provavelmente o intérprete vai se portar como um piloto suicida, posto que a escolha do legislador constituinte por uma sociedade plural importa em desafios interpretativos à luz de vários projetos que aglutinam grupos de indivíduos em uma convivência e em uma disputa social de planos múltiplos. Como ensinam Galuppo, Cruz e Sampaio (2004, p. 53-54):

Evidentemente, a defesa do pluralismo é uma característica do Estado Democrático de Direito, paradigma que a Constituição do Brasil prescreve não só como modelo de Estado, mas também como projeto para a sociedade. Podemos distinguir os três paradigmas do Estado Moderno, a saber, o Estado Liberal, o Estado Social e o Estado Democrático de Direito, dentre outros meios, pela maneira como tratam o pluralismo. O Estado Liberal pressupunha uma forma de organizaçáo social baseada no consenso radical e homogêneo entre os indivíduos que o compunham, desconfirmando, como irrelevante, o dissenso, e impondo um único 
projeto, a saber, o projeto hegemônico daqueles que controlavam o poder central. O Estado Social, por sua vez, pressupunha que se, materialmente, existiam conflitos entre os projetos dos mais variados grupos sociais, era, no entanto, possível eliminar juridicamente estes conflitos, impondo-se um projeto "alternativo" e arbitrário que "corrigisse" as distorções produzidas pelo poder econômico e anulasse o próprio conflito. Ao contrário, o Estado Democrático de Direito pressupôe que o pluralismo é constitutivo da própria sociedade contemporânea, e que, portanto, não se pode, legitimamente, eliminar qualquer projeto de vida sem se interferir na autoidentidade de uma determinada sociedade. Ao contrário, ele deve reconhecer que todos os projetos que compóem uma sociedade, inclusive os minoritários, são relevantes na composição de sua identidade.

O que se pode compreender com base nos ensinamentos retroapresentados é que uma sociedade plural é, por excelência, uma realidade na qual as escolhas individuais são variadas e com a convivência ao lado de conflitos inerentes a diversos posicionamentos e pontos de vista. A escolha do legislador constituinte de 1988 pelo pluralismo consiste na aceitação da heterogeneidade. A sobrevivência da sociedade pluralista está condicionada à tolerância. Dito de outra maneira, a busca pela homogeneidade era modelo inerente ao Estado Liberal, mas que não se enquadra no paradigma do Estado Democrático de Direito. Ao escolher a convivência com as diferentes maneiras de pensar e, por consequência, de expressar visôes distintas e, até mesmo, divergentes, há que se consagrar a necessidade de limitaçóes que possibilitem, sobretudo, a tolerância (GALUPPO; CRUZ; SAMPAIO, 2004).

Eis o grande imbróglio que envolve o exercício das liberdades democráticas, especialmente o direito de liberdade de expressão: respeito à sociedade plural, aceitação das diferenças sem ferir, distorcer, desrespeitar outros direitos fundamentais. $\mathrm{O}$ direito à não discriminação prescrito no art. $3^{\circ}$, IV, da Constituição Federal apregoa como objetivo fundamental do Estado Brasileiro a promoção do bem de todos, sem preconceito de origem, raça, sexo, cor, idade ou quaisquer outras formas de discriminação.

A vedação a toda e qualquer discriminação como norma constitucional é o alicerce da declaração de que o Estado Democrático Brasileiro faz a opção pelo pluralismo, e a Constituiçáo, ao mesmo tempo, assegura a todos o direito de se manifestarem livremente sob as mais variadas formas (artística, intelectual, cultural, científica), expressando opiniōes e consideraçóes sobre variados assuntos 
e temas. Obviamente, portanto, não há uma autorização constitucional para a ofensa e a discriminação. Pelo contrário, confirmando o que já foi abordado, o texto constitucional só tem sentido se interpretado sob o comando do princípio da unidade.

Friedrich Muller defende o princípio da unidade da Constituição como solução para conflitos entre normas constitucionais. Explica o autor que "a 'unidade da constituiçáo' enquanto visão orientadora (Leitbild) da metódica do direito constitucional deve antepor aos olhos do intérprete, enquanto ponto de partida, bem como, sobretudo, a totalidade da constituição como um arcabouço de normas" (MÜLLER, 1999, p. 84). As tensôes estâo presentes e o intérprete deve procurar ajustar eventuais contradiçóes como resultados parciais no processo da concretização, a fim de buscar um resultado harmônico. A Constituição, segundo ele, não aponta que procedimento deve ser adotado a fim de se perseguir a harmonia almejada pelo intérprete. $\mathrm{O}$ procedimento consiste nas possibilidades da interpretação sistemática, na inclusão dos aspectos sistemáticos da análise do âmbito da norma e, genericamente, em um procedimento adicional de interpretação harmonizadora com vistas a superar as antinomias surgidas (MÜLLER, 1999).

Tomando-se, portanto, o parâmetro do princípio da unidade da Constituição, fica evidente que ao intérprete não é possível optar por uma norma em detrimento de outra que, também e igualmente, seria aplicável na solução de um caso concreto, tendo em vista a inexistência de hierarquia entre as normas constitucionais principiológicas.

\section{Liberdade de expressáo náo é discurso de ódio}

Tendo por base os pontos supra-abordados, nos quais se constata que a Constituição Federal de 1988 opta pela aceitação das diferenças e estabelece a impossibilidade do consenso ao se firmar sob a égide da edificação da sociedade plural, pode-se avançar agora para o ponto nevrálgico deste trabalho: a análise do exercício da liberdade de expressáo como escusa para a propagação de discursos de ódio, preconceito e discriminaçáo contra diferentes pessoas e grupos. Claro que as minorias são sensivelmente mais atacadas pelo hate speech em relação às ditas maiorias. Em tempos de utilização do ciberespaço por meio de inúmeros instrumentos tecnológicos, como redes sociais e aplicativos de telefonia móvel, há maior vigor no acesso a informaçóes e no exercício da liberdade de expressão.

Ora, em tempos antecedentes às redes de comunicaçáo social pela internet, logo no surgimento da rede mundial de conexão de computadores, havia a possibilidade de divulgação de informaçóes e notícias, via portais, sites e 
comunicaçôes restritas por e-mail. No contexto atual, porém, as opiniôes emitidas no ciberespaço se alastram em fraçóes de segundo, em dimensões nunca antes imagináveis.

O que causa espanto e indignação é a indevida e inadvertida utilização desses instrumentos para o exercício da liberdade de expressão sem o contraponto reflexivo sobre a possibilidade de abalo a outros direitos fundamentais, sobretudo o direito à não discriminação, o que afeta diretamente também o princípio constitucional da dignidade da pessoa humana - base e fundamento da ordem jurídica pátria fundada a partir da Lei Fundamental de 1988.

A liberdade de expressão tornou-se "direito curinga" para justificar absurdos, ofensas, impropérios e ataques covardes disparados contra pessoas e grupos que professam uma determinada religiáo ou que não professam nenhuma; contra pessoas com determinada orientação sexual; contra pessoas de determinada cor ou contra aqueles que não se enquadram nos padrôes estéticos ditados pelo mercado da "moda e estilo".

Haveria, assim, um abuso da liberdade de expressão em tempos de Pós-Modernidade? Haveria uma crise no exercício de direitos conquistados por meio de revoluçóes e movimentos de resistência a tiranias? Ou seria um grande exagero interpretar o uso de discursos de ódio como ameaças ao direito de liberdade de expressáo?

A liberdade de expressão é alicerce do Estado Democrático de Direito, pressupóe o multiculturalismo e não se confunde com discursos de ódio. $\mathrm{O}$ ataque ofensivo às minorias e à intolerância são, na verdade, mecanismos de desconstrução do próprio Estado Democrático de Direito, que tem como pressuposto elementar a visão pluralista. Ao adotar o pluralismo como fundamento, a Constituição estabelece o respeito à liberdade de toda pessoa humana em pertencer a várias comunidades de ordem moral, cultural, espiritual, científica, intelectual e política. O princípio pluralista, no qual se baseia o texto constitucional, é, portanto, cerne indissociável do princípio democrático - base do Estado Democrático de Direito - e não admite o discurso fundado no ódio às diferenças de posicionamento e de concepçôes de vida em sociedade.

Não há respostas prontas e seguras acerca dos questionamentos propostos anteriormente, uma vez que muitos fenômenos atrelados à evoluçáo tecnológica antes inexistente passaram a ser corriqueiros no dia a dia de milhóes de pessoas e perpassam por múltiplos processos investigatórios de várias áreas do conhecimento científico. O Direito, como ciência sempre contextualizada, segue ou tenta seguir e acompanhar o curso do processo evolutivo das demais áreas do saber, tendo o propósito regulamentatório das relações sociais como seu escopo. É o que se deduz tendo por base o seguinte aresto: 
No jusnaturalismo racionalista e secularizado que inspirou o constitucionalismo, os direitos humanos eram vistos como direitos inatos e tidos como verdade evidente. A sua positivação constitucional através de Declaraçôes, que se inicia no século XVIII, com as Revoluçōes Americana e Francesa, tinha como objetivo conferir aos direitos nela contemplados uma dimensão permanente e segura. Essa dimensão seria o dado de estabilidade, que serviria de contraste e tornaria aceitável a variabilidade, no tempo e no espaço, do Direito Positivo dependente da vontade do legislador, em contextos localizados e variáveis. Essa variabilidade é explicável, pois o Direito no mundo moderno passou a ter a dinâmica de um instrumento de gestão de uma sociedade em mudança (LAFER, 2004, p. 57).

Condutas amparadas em preconceitos, que nada mais são do que prejulgamentos e generalizaçôes irrefletidas, configuram visões distorcidas acerca do exercício dos direitos fundamentais. Aquele que se julga no direito de promover discriminaçóes por entender que está em um patamar de superioridade não vê o outro como titular também dos mesmos direitos fundamentais. $\mathrm{O}$ não reconhecimento do outro aos mesmos direitos chama atenção para o problema de uma sociedade que deveria se pautar pelo pluralismo como condição de aceitação de múltiplos pontos de vista e das minorias. A convivência com as diferenças e com o dissenso é o eixo condutor do regime democrático.

O direito de liberdade de expressáo, assim como qualquer outro direito fundamental, só é passível de limitaçôes e restriçôes quando necessárias para uma adequação interpretativa nas rotas de colisão com outros direitos fundamentais, uma vez que, como já explicitado, não há hierarquia entre tais direitos. Escancarar ódio, preconceito e discriminação contra pessoas em situação de vulnerabilidade minoritária não é, nem nunca foi, o escopo protetivo da liberdade de expressão.

O direito que estabelece a liberdade de expressar, manifestar, opinar, expor... não acoberta discriminaçôes atentatórias à dignidade humana. Há limites. Os limites são estabelecidos no próprio texto constitucional que o consagra, na legislação infraconstitucional, assim como são também albergados na interpretação realizada diante de casos concretos.

A primazia da tolerância, como característica intrínseca da sociedade plural, reflete na tipificação de condutas penais, o que obviamente também resvala na opção do ordenamento jurídico por cercear comportamentos percebidos sob os comandos de discursos de ódio. Acerca da tolerância como elemento de definição ou de indefinição de crimes na ordem penal, traz-se à baila a lição: 
O legislador penal, no diálogo, v.g., com a criminologia, detecta os valores mais expressivos da comunidade, que necessitam de intervençấo penal, passando, pois, a criminalizar.

$[\ldots]$

Já deixamos adiantado, portanto, que a tolerância terá reflexos sobre a

(A) política de criminalização e de descriminalização. Mas, também, podemos destacar, seguindo a esteira de Virgilio Latorre Latorre, outras categorias dogmáticas do direito penal que revelam a influência exercida pela tolerância. É o caso do (B) juízo que se faz da antijuridicidade, principalmente no que toca às categorias de excludentes de ilicitude e de punibilidade. E do (C) juízo de culpabilidade.

$[\ldots]$

Disto podemos concluir que a tolerância, antes de representar um estado de passividade, projeta-se ativamente a partir das comunicaçôes interpessoais para o plano da institucionalização, sendo capaz de gerar fenômenos jurídicos

Em conclusão, podemos dizer que: a) a tolerância não poderá ser absoluta ao ponto de permitir tudo, inclusive o intolerável, sob o risco de negar-se e desestabilizar a sociedade; b) não se confunde com a neutralidade, com a indiferença ou com a passividade; c) isto porque atua de forma ativa no mundo jurídico, legitimando direitos e mesmo criando-os; d) de forma que, neste processo, a tolerância assume um papel ambivalente: pois que o direito criado ou confirmado é, ao mesmo tempo, tolerante para com os fatos ou atos jurídicos permitidos e intolerante para com o seu desrespeito, impondo sistema de controles ou sançóes (GUIMARĀES, 2001).

Há meios jurídicos à disposição de todos que tiverem seus direitos fundamentais aviltados por aqueles que, sob a forma equivocada de exercício do direito de liberdade de expressão, praticam condutas passíveis de sanção penal el ou reparo no âmbito do Direito Civil.

Como exemplo do repúdio a práticas discriminatórias no ordenamento pátrio, merecem destaque os incs. XLI e XLIV do art. 50 da Lei Fundamental por determinarem que se estabeleça puniçáo infraconstitucional a atos atentatórios aos direitos e liberdades fundamentais e por considerar a prática do racismo crime inafiançável e imprescritível. ${ }^{9}$ Para elucidar com mais precisão, são essenciais os entendimentos de José Afonso da Silva:

9 No ano de 1989, foi editada a lei 7.716, que determina: "Art. 1º- Serăo punidos, na forma desta Lei, os crimes resultantes de discriminação ou preconceito de raça, cor, etnia, religião ou procedência nacional” (CARVALHO, 2009). 
Os incisos aqui considerados constituem garantias penais dos direitos fundamentais - incluindo o princípio democrático - consubstanciado no art. $1^{\circ}$. Protegem, especialmente, o direito de igualdade, configurado no caput do art. $5^{\circ}$

[...]

Em regra, toda discriminação é atentatória aos direitos fundamentais

[...]

A discriminação condenada é a que se funda num preconceito negativo em virtude do qual os membros de um grupo são tratados como seres nấo já diferentes, mas inferiores. É nesse sentido que a discriminação é de considerar-se atentatória a direito fundamental (SILVA, 2008, p. 139).

As ideologias discriminatórias e nocivas são repelidas pela Constituição. Não há nenhum respaldo, em nome da liberdade de pensamento, de expressão ou de convicçóes filosóficas ou científicas, bem como de manifestaçôes artísticas que acatem ou admitam a ideia de domínio de uma determinada raça ou de outras práticas atentatórias à dignidade humana (SILVA, 2008).

As liberdades fundamentais até aqui merecedoras de análise e atenção especial não são positivadas como direitos constitucionais de aterrorizar e humilhar qualquer ser humano ou grupo a que pertença, mesmo tratando-se de posiçóes minoritárias no cenário político-social. O princípio da igualdade, também escancarado na Lei Fundamental, formaliza o sentido de tratamento isonômico que deve ser obrigatoriamente concedido a todos, independentemente de gênero ou qualquer outra condição. $\mathrm{O}$ mesmo texto constitucional determina diferenciaçóes que permitam apenas as chamadas discriminaçôes positivas em verdadeiros comandos de observação pelo legislador infraconstitucional no dever de criar instrumentos que possibilitem a materialização da igualdade na prática. Para melhor entender:

A influência do princípio igualitário será profunda em qualquer sociedade que o aceite. A interpretação preferida da consideraçâo igualitária influirá não só no projeto de todas as instituiçôes fundamentais do governo, mas também nas decisôes específicas tomadas por essas instituiçôes (DWORKIN, 2002, p. 253). 


\section{Conclusão}

A liberdade de expressão configura-se como direito fundamental ao lado de outras liberdades essenciais ao espectro condutor garantista da dignidade humana no Estado Democrático de Direito, fundado sob o prisma do pluralismo na Constituição de 1988.

Entre as várias características dos direitos fundamentais, pode-se destacar a limitabilidade, que pode ser entendida pelo afastamento da possibilidade de exercício desses direitos em caráter absoluto. Obviamente que as restriçóes impostas ao exercício desses direitos devem ser adequadas e necessárias, não sendo possível uma generalização limitativa.

O direito de liberdade de expressão não é, portanto, irrestrito, posto que seu exercício está vinculado à observância de outras normas constitucionais, em interpretaçóes calcadas no princípio da unidade da Constituição.

Discursos de ódio que arraigam preconceitos e discriminaçóes não estão amparados pela Lei Fundamental, não importa sobre qual assunto versem. Para ficar em único exemplo: o mesmo direito de liberdade de consciência e crença sustenta a possibilidade de se conviverem certezas tanto da existência quanto da não existência de um Ser Superior.

A sociedade plural é, por excelência, a sociedade heterogênea, marcada pelo dissenso. Só é possível o convívio harmônico sob a perspectiva pluralista mediante o hasteamento da bandeira da tolerância. Conclui-se que a liberdade de expressão não é aval para discursos de ódio e intolerância. $\mathrm{Na}$ era da Pós-Modernidade há novos instrumentos tecnológicos que permitem uma amplitude na forma de cada indivíduo expressar suas visões de mundo, suas ideologias, suas manifestaçóes artísticas, intelectuais e científicas. As redes sociais deram ampla abertura para o exercício da liberdade de expressão, porém não há guarida para a disseminação de posicionamentos de intolerância, preconceitos e discriminaçóes. Em tempos de fake news é importante realçar que o discurso de ódio importa em diminuição, humilhação e discriminação de grupos minoritários, o que fere a consagração do pluralismo como base de sustentação do regime democrático.

Não há licença para o ataque ofensivo e humilhante. A opinião divergente é o centro do dissenso pluralista e assim há de ser. A dissidência pluralista de ideias, sem o acatamento no mesmo patamar das variadas opçóes e argumentos, longe do engessamento ao enquadramento de posicionamentos majoritários, implica o exercício ao direito de liberdade de expressão e não concede licença para o discurso de ódio. A forma diferente de viver ou pensar năo significa superioridade ou inferioridade de convicçóes estabelecidas por cada ser no exercício de sua 
individualidade; significa apenas e simplesmente que as distinçóes que fazem cada ser único têm de ser toleradas e respeitadas e com amparo do ordenamento jurídico.

Por fim, pode-se concluir que o Estado Democrático de Direito é construído sob as bases fundamentais do pluralismo, o que pressupóe respeito e tolerância ao multiculturalismo, sendo inadmissível o discurso de ódio. Quando o discurso de ódio se confunde com o direito de liberdade de expressão, o próprio Estado Democrático de Direito é atacado.

\section{Referências}

BONAVIDES, P. Curso de Direito Constitucional. 25. ed. São Paulo: Malheiros, 2010.

CARVAlHO, K. G. Direito Constitucional. 15. ed. Belo Horizonte: Del Rey, 2009.

DECLARAÇÃO de direitos do homem e do cidadão. 26 de agosto de 1789. França. Biblioteca Virtual de Direitos Humanos da Universidade de Sáo Paulo. Disponível em: http://www.direitoshumanos.usp.br/index.php/Documentos-anteriores-à-criação-da-Sociedade-das-Nações-até-1919/declaracao-de-direitos-do-homem-e-do-cidadao-1789.html. Acesso em: 12 ago. 2019.

DWORKIN, R. Levando os direitos a sério. São Paulo: Martins Fontes, 2002.

GALUPPO, M. C.; CRUZ, A. S.; SAMPAIO, J. A. L. Hermenêutica e jurisdição constitucional. Belo Horizonte: Del Rey, 2004.

GUIMARÁES, I. S. Tolerância: elemento de Intercorrência na Redefinição do Direito Penal. Revista Jurídica da Unisul, Tubarão, v. 2, n. 2, p. 69-84, 2001.

LAFER, C. O caso Ellwanger: antissemitismo como crime da prática do racismo. Revista de Informaçâo Legislativa, Brasília, v. 41, n. 162, p. 53-89, abr.-jun. 2004.

MENDES, G. F.; BRANCO, P. G. G. Curso de Direito Constitucional. 9. ed. São Paulo: Saraiva, 2014.

MÜlLER, F. Métodos de trabalho do Direito Constitucional. 2. ed. Porto Alegre: Max Limonad, 1999.

ONU (ORGANIZAÇÃO DAS NAÇÓES UNIDAS). Declaração Universal dos Direitos Humanos. Nova York: ONU, 1948.

PIOVESAN, F. Direitos Humanos e Princípio da Dignidade da Pessoa Humana. 
In: LEITE, G. S. (Org.). Dos princippios constitucionais: consideraçôes em torno das normas principiológicas da Constituição. São Paulo: Malheiros, 2003. p. 180 $-193$.

PIOVESAN, F. Direitos Humanos e o Direito Constitucional Internacional. São Paulo: Saraiva, 2011.

SARLET, I. W. Dignidade da pessoa humana e direitos fundamentais na Constituição da República de 1988. Porto Alegre: Livraria do Advogado, 2002.

SARLET, I. W. A eficácia dos direitos fundamentais. 5. ed. Porto Alegre: Livraria do Advogado, 2005.

SCHREIBER, S. Colisão de Direitos Fundamentais: uma investigação sobre as consequências e formas de superação do confronto entre o direito a um julgamento justo e imparcial e a liberdade de expressão e informação. In: PEIXINHO, M. M.; GUERRA, I. F.; NASCIMENTO FILHO, F. (Orgs.). Os Princípios Constitucionais da Constituição de 1988. Rio de Janeiro: Lumen Júris, 2006. p. 289-308.

SILVA, J. A. Comentário contextual à Constituição. 5. ed. São Paulo: Malheiros, 2008, p. 139. 